\title{
Engagement Markers in L1 and L2 English Academic Writing: The case of Master's and Doctorate Theses ${ }^{1}$
}

\author{
Fatma YUVAYAPAN \\ Assist. Prof. Dr., Kahramanmaras İstiklal University, \\ Faculty Of Humanities And Social Sciences, \\ Department Of Translation and Interpreting \\ fyuvayapan@gmail.com \\ Orcid ID: https://orcid.org/ 0000-0002-7924-0933

\section{İlyas YAKUT} \\ Assist. Prof. Dr., Kahramanmaras İstiklal University, \\ Faculty Of Humanities And Social Sciences, \\ Department Of Translation and Interpreting \\ yakutilyas@gmail.com \\ Orcid ID: https://orcid.org/0000-0001-9680-4561
}

\begin{abstract}
Engagement markers are linguistic devices through which academic writers pull their readers into their texts and negotiate with them. This particular form of negotiation is crucial for the acceptance of new academic knowledge claimed by academic writers in addition to meeting the expectations of readers who are highly proficient scholars, specifically in postgraduate genres. Based on contrastive interlanguage analysis, this study investigates engagement markers emerging in master's and doctoral dissertations in the English language-related studies written by L1 English speakers and Turkish speakers of English in the last ten years between 2010 and 2019. This study suggested that L1 English academic writers employed more engagement markers in their master's and doctorate theses than Turkish academic writers of English. In addition to cross-cultural variations in the two academic communities, we observed identical strategies in master's and doctorate theses by both groups of academic writers. This study offers significant implications for academic writers producing work in the English language as the engagement marker usage in L1 English academic writing might guide L2 speakers of English in identifying appropriate engagement markers.
\end{abstract}

\footnotetext{
${ }^{1}$ Article Arrival/Acceptance Date: 08.01.2020 / 18.04.2021

Reference Information: Yuvayapan, F. and Yakut, İ. (2021). Engagement markers in L1 and L2 English academic writing: the case of master's and doctorate theses. Kahramanmaraş Sütçü Imam University Journal of Social Sciences, 18 (3), 1658-1670. DOI: 10.33437/ksusbd.963087
} 
Anahtar Kelimeler: Academic Writing, Postgraduate Genres, Engagement markers, L1 English speakers, Turkish speakers of English.

\title{
Birinci ve İkinci Dil Olarak İngilizce Akademik Yazımda İlişki Belirteçleri: Yüksek Lisans ve Doktora Tezleri Örneği
}

\begin{abstract}
İlişki belirteçleri, akademik yazarların okuyucularını metinlerine çektiği ve onlarla müzakere ettiği dilsel araçlardır. Bu özel müzakere biçimi, özellikle lisansüstü türlerde oldukça yetkin akademisyenler olan okuyucuların beklentilerini karşılamanın yanı sıra, akademik yazarlar tarafından ortaya atılan yeni akademik bilgilerin kabulü için de çok önemlidir. Karşılaştırmalı aradil çözümlemesine dayanan bu çalışma, 2010 ve 2019 yılları arasında birinci dil olarak İngilizce konuşan ve ikinci dil olarak İngilizce konuşan Türk yazarlar tarafından yazılan İngilizce araştırmaları ile alakalı yazılmış olan yüksek lisans ve doktora tezlerinde ortaya çıkan ilişki belirteçlerini araştırmaktadır. $\mathrm{Bu}$ çalışmanın sonuçları, birinci dil olarak İngilizce konuşan yazarların yüksek lisans ve doktora tezlerinde ikinci dil olarak İngilizce konuşan Türk yazarlara kıyasla daha fazla ilişki belirteci kullandıklarını göstermiştir. İki akademik topluluktaki kültürler arası farklılıklara ek olarak, her iki akademik yazar grubunun yüksek lisans ve doktora tezlerinde aynı stratejileri kullandıkları gözlemlenmiştir. Bu çalışma, İngilizce dilinde eser üreten akademik yazarlar için önemli çıkarımlar sunmaktadır, çünkü birinci dil olarak İngilizce konuşan araştırmacıların akademik yazımda ilişki belirteci kullanımı, ikinci dil olarak İngilizce konuşanlara doğru ilişki belirteçlerini belirlemede rehberlik edebilir.
\end{abstract}

Keywords: Akademik Yazım, Lisansüstü Türler, İlişki Belirteçleri, Birinci Dil Olarak Ingilizce Konuşuculari, İkinci Dil Olarak İngilizce Konuşan Türkler.

\section{INTRODUCTION}

Irvin (2010) defines academic writing as "the form of evaluation that asks you to demonstrate knowledge and show proficiency with certain disciplinary skills of thinking, interpreting and presenting” (p. 8). Molino (2010) identifies academic writing as a social activity in which knowledge is constructed based on social validation. In recent decades, academic writing has lost its faceless, impersonal, and objective rhetoric and is now considered as a persuasive attempt centered on interaction with readers. This new view sees academics shape their texts to readers' expectations to reduce the risk of readers' objection to their claims and arguments (Hyland, 2005a). Reflecting the acceptance of new claims 
by the disciplinary community and the contribution of the research to the field, academic persuasion also involves;

the ability of the writer to anticipate criticism, to represent him/herself as a reliable source of information, and to persuade readers of the relevance, validity, and novelty of his/ her claims and views while presenting them as coherent with previous disciplinary knowledge (Dontcheva-Navrátilová, 2018: 227).

Complex linguistic strategies rested on interpersonal and ideational sources are required to meet the expectations of academic persuasion (DontchevaNavrátilová, 2018; Vazquez and Giner, 2009). While producing texts in line with these expectations, academic writers utilize rhetorical devices to maintain readers' engagement. One way this interaction in the text can be realized is the use of engagement markers (EMs).

Thompson (2001) calls engagement as "reader-in-the-text". Mur Duenas (2008) defines EMs as features that bring readers into the text to fulfill the negotiation of meaning. This negotiation is essential for accepting new academic knowledge by the readers and establishing solidarity with colleagues. EMs display writers' dialogic awareness that can be established by treating readers as "the real players of the text rather than merely implied observers of the discussion” (Hyland, 2001:552). As for Hyland (2005a), engagement reflects how writers embody propositional content to make it relevant to their readers. EMs "are devices that explicitly address readers, either to focus their attention or to include them as discourse participants" (Hyland, 2005b: 53). Writers need to balance the existence of their readers in their texts to;

a- address readers' expectations of inclusion and manifest disciplinary solidarity through the use of reader pronouns and interjections

b- direct their readers to some critical points using questions, directives, modals, and references to shared knowledge.

Hyland (2005a) identifies five main elements of engagement. As the most explicit way of bringing readers into texts, reader pronouns are the means of constructing membership by binding writers and readers as participants of the texts. Personal asides enable writers to address their readers directly, while appeals to shared knowledge bring readers into the text within the boundaries of disciplinary understandings. This said, readers are expected to recognize familiar concepts of the field. Directives are instructional strategies to perform an action determined by the writer. By arousing interest, questions encourage readers to figure out an unresolved issue. 


\section{F.Yuvayapan-İ.Yakut $\quad$ Engagement Markers in L1 and L2 English...}

Being a leading figure in metadiscourse and engagement, Hyland (2001) examined the construction of readers' participation in a corpus of 240 research articles in eight disciplines and disciplinary variations. He suggested that clear awareness and engagement of readers are the prerequisites of successful academic writing. In another study, Hyland (2002) focused on the use of directives in a corpus, including published articles, textbooks, and L2 students' essays, and revealed different employment of directives in different genres and disciplines. Directives bring readers academic texts in three ways: textually (a part of the text), physically (a research process or real-world action), and cognitively (a new argument). In a recent diachronic study, Hyland and Jiang (2016) trace the changes in the use of EMs over the 50 years. The analysis of three corpora consisting of research articles in four disciplines revealed that academic writers have started to utilize more EMs than the occurrences in the past.

McGrath and Kuteva (2012) carried out a study that examined writing practices in pure mathematics and observed frequent use of shared knowledge markers. Koutsantoni (2004) analyzed how electrical engineers employed shared knowledge to present new claims based on consensual understandings. Examining the use of EMs in native English students' oral presentations extracted from MICASE corpus, Mameghani and Ebrahimi (2017) found that 'you' and 'see' were the most common EMs, although this pronoun is not applied in written academic genres. In a diachronic analysis of research articles in humanities and science, Sahragard and Yazdanpahani (2017) showed that EM usage increased in the 1990s and 2000s. Directives were employed at high frequencies in both disciplines.

Among academic genres, MA and Ph.D. theses are two prominent postgraduate genres that are the first step of being a member of academic communities. Clearly, in these two specific academic genres, writers are expected to provide a reasonably good representation of the linguistic norms of the academic disciplines and meet the expectations of readers composed of scholars and specialists in the thesis defense committee. Apparently, EMs have been investigated in various academic genres, but no previous study has carefully examined the construction of engagement in master's (MA) and doctorate (Ph.D.) theses in L1 and L2 English contexts. Considering this gap, we attempt to compare EM usage of L1 English academic writers and Turkish academic writers of English in their MA and Ph.D. theses produced in English language-related fields. The following research questions constituted the essence of the study.

1. What types of EMs do L1 English academic writers and Turkish academic writers of English employ in MA and Ph.D. theses? 
2. Do L1 English academic writers and Turkish academic writers of English differ significantly in the use of EMs in MA and Ph.D. theses?

3. What are the most common EMs employed by L1 English academic writers and Turkish academic writers of English in MA and Ph.D. theses?

\section{METHODOLOGY}

\section{The Corpus}

The data for this study consist of four corpora of MA and Ph.D. dissertations produced in the English language-related studies by L1 English speakers and by Turkish speakers of English in the last ten years between 2010 and 2019. Informed consent of the authors was obtained in the process of corpus compilation, and the corpora consisted of dissertations constructed through a convenience sampling technique. The sections included in the corpora were introduction, results and discussions, and conclusion. Suffice to add that all quotations and paraphrases were excluded to avoid possible interference of other authors cited in the dissertations.

The theses were converted into text file format to produce an electronic corpus of 1.148.992 words in total. The MA corpus written by L1 academic writers of English (CMAN) was represented by 12 theses of 121.846 words, while the MA corpus written by Turkish academic writers of English (CMAT) was a collection of 19 MA theses totaling 320.169 words. The Ph.D. corpus, written by L1 academic writers of English (CPhDN), was amounted to 322.475 words gathered from 16 theses. The Ph.D. corpus, written by Turkish academic writers of English $(\mathrm{CPhDT})$, included 384.502 words and 15 theses.

\section{Data Analysis}

Initially, we decided to work on larger corpora, yet CMAN only ran to 121.846 words in a period of six months. Since it was not ethical to add theses to the corpus without getting the writers' consent, we decided not to use any open-access theses to compile this corpus. However, to ensure a standard basis for comparing metadiscursive (MD) nouns in the corpora, the raw frequency counts of each category of MD nouns were normalized to 1000 words. To calculate the normalized frequency of each category, we multiplied raw frequencies by 1000 . And then, the outcome was divided by the size of the corpus.

The study considered the analysis of all EMs proposed in Hyland's (2005b) taxonomy of metadiscourse. Eighty items of EMs included adverbials, verbs, modals, nouns, and pronouns, among which the verbs were the most varied ones with 63 items. To observe the concordances of items of EMs in each corpus, 
AntConc version 3.5.8 (Anthony, 2019), a freeware corpus analysis toolkit, was utilized.

We uploaded each corpus to the software, and the frequency of each item in the taxonomy was examined individually through a vertical reading. An in-depth horizontal analysis was conducted to ensure that all occurrences of each item could function as EMs. A number of tokens that could not have an engagement function were eliminated.

After all occurrences of each item of EMs were calculated, the raw frequencies were normalized per 1000 words to ensure a standard basis for the comparisons of EMs in the corpora. The percentages of EMs found in the four corpora were also calculated. Log-likelihood (LL) statistics were performed to explore whether EMs usage across the four corpora statistically differed. As Baker, Hardie, and McEnery (2006) state, LL is a test utilized to calculate statistical significance that is commonly applied in corpus analysis, and it is available at http://ucrel.lancs.ac.uk/llwizard.html.

\section{FINDINGS AND DISCUSSION}

The total number of 80 items of EMs were analyzed in the four corpora, as displayed in Table 1. CMAN consisted of 121.846 words, while the number of words in CMAT was 320.169. EMs were observed 8.6 and 6.6 times per 1000 words in CMAN and CMAT, successively. Similarly, they were heavily represented in $\mathrm{CPhDN}$ with 8.2 than $\mathrm{CPhDT}$ at 6.6 frequency counts per 1000 words.

Table 1. Overall Distribution of EMs in the Four Corpora

\begin{tabular}{|c|c|c|c|c|}
\hline & CMAN & CMAT & CPhDN & CPhDT \\
\hline Corpus size in words & 121846 & 320169 & 322475 & 384502 \\
\hline $\mathbf{n}$ & 1050 & 2130 & 2963 & 2560 \\
\hline $\mathbf{n} / \mathbf{1 0 0 0}$ & 8.6 & 6.6 & 8.2 & 6.6 \\
\hline $\mathbf{\%}$ & 12 & 25 & 34 & 29 \\
\hline
\end{tabular}

n: raw frequency of EMs

n /100: frequency of EMs per 1000 words

\%: percentage of EMs

Apparently, Turkish academic writers of English (TAWEs) utilized fewer EMs in their MA and Ph.D. theses compared to L1 academic writers of English (NAWEs), which is occasionally due to cross-culturally oriented conventions of academic writing. As Hyland (2004) states, rhetorical decisions of academic writers to argue and engage their readers to reflect discourse practices of 
disciplinary communities. Additionally, in both academic communities, fewer EMs were used in MA theses than in Ph.D. theses. Bastola (2020) explains the reasons for the difficulties of thesis writing at the MA level: inexperience and limited understandings of thesis requirements. MA students might not have sufficient knowledge of their disciplinary communities' linguistic conventions in our corpus. Hence, they might use fewer EMs in their MA theses.

Dontcheva-Navrátilová (2021) points out that previous cross-cultural studies have revealed numerous factors affecting writers' interaction with readers: "epistemological traditions, politeness conventions and the level of homogeneity of the national culture, focusing on divergences in the use of metadiscourse markers” (p.19). Some of these factors may influence the use of EMs by both groups of academic writers in our study. Writer-reader interaction in postgraduate genres is not egalitarian due to the characteristics of readers who are highly proficient scholars in their fields. Addressing readers as if they were their colleagues may probably be risky for postgraduate academic writers. Hence, TAWEs tend to cultivate a kind of academic distinction of power and status between them and their readers.

Additionally, TAWEs are novice academic writers of English; thus, they may lack awareness and knowledge of the linguistic conventions of this international academic community. They may opt for a more subjective presentation of the findings and their claims rather than a marked preference for a high level of writer-reader interaction. They get behind their claims and leave a space for the negotiation of these claims with their readers. On the other hand, NAWEs tended to use more EMs in their MA and Ph.D. theses compared to TAWEs. Nonnative academic writers of English have to publish studies in English to become a member of the international academic community with the spread of English as the lingua-franca of this community and adapt a different literary convention to interact with their English readers (Dontcheva-Navrátilová, 2013). Being native speakers of English, NAWEs are already members of this international community, and they are familiar with the conventions of this community.

Looking at the normalized results, we can conclude that the employment of EMs was not distinguishable in MA and Ph.D. theses written by TAWEs and NAWEs, which is not consistent with Hyland (2004), who found that L2 Ph.D. students applied more stance and engagement markers compared to MA students. Thus, it is clear that the study level does not seem to impact EM usage in L1 and L2 English contexts. The projection of readers in both genres seemed to be identical in these two different academic cultures. A cause of this could be a common tendency to leave thesis evaluation to readers. It is likely that both groups of academic writers may not be aware of the rhetorical requirements of these two different genres regarding readers' engagement. Another reason may 
F.Yuvayapan-İ.Yakut $\quad$ Engagement Markers in L1 and L2 English...

be the influence of individual writing style, as Burneikaite (2008) and Hyland (2002) suggest.

We conducted LL statistics to calculate whether the difference of frequency counts in the four corpora was statistically significant. As shown in Table 2, there was significant underuse of EMs by TAWEs in their MA theses compared to NAWEs (-45.63), supported by 0.0002 ELL. Similarly, the -143.01 LL ratio value proved significant underuse of EMs by TAWEs compared to NAWEs in $\mathrm{Ph} . \mathrm{D}$. theses. This finding supports our claims about the lack of rhetorical awareness by L2 English academic writers alongside linguistic-cultural differences.

Table 2. LL Ratio of EMs in the Four Corpora

\begin{tabular}{|c|c|c|c|c|c|c|}
\hline & $\begin{array}{c}\text { CMAT } \\
\mathbf{n}\end{array}$ & $\begin{array}{c}\text { CMAN } \\
\mathbf{n}\end{array}$ & $\begin{array}{c}\text { LL Ratio } \\
\mathbf{( p < \mathbf { 0 . 0 5 } )}\end{array}$ & $\begin{array}{c}\text { CPhDT } \\
\mathbf{n}\end{array}$ & $\begin{array}{c}\text { CPhDN } \\
\mathbf{n}\end{array}$ & $\begin{array}{c}\text { LL Ratio } \\
\mathbf{( \mathbf { p } < \mathbf { 0 . 0 5 } )}\end{array}$ \\
\hline EMs & 2130 & 1050 & -45.63 & 2560 & 2963 & -143.01 \\
\hline
\end{tabular}

n: raw frequency of EMs

A glance at Table 3 indicating the most frequent ten EMs in the four corpora shows that six of ten most prevalent EMs were verbs. Since 63 of EMs in the taxonomy were verbs, this finding can be anticipated. The pervasive use of the items 'see', 'should', and 'we' were observed in the four corpora. Mur-Duenas (2008) found that 'see' and 'should' are the most common EMs in the native corpus of the study.

Table 3. Ten Most Frequent EMs in the Four Corpora

\begin{tabular}{|c|c|c|c|c|c|c|c|c|c|c|c|}
\hline \multicolumn{3}{|l|}{ CMAN } & \multicolumn{3}{|l|}{ CMAT } & \multicolumn{3}{|l|}{ CPhDN } & \multicolumn{3}{|l|}{ CPhDT } \\
\hline EMs & $\mathrm{n}$ & $\begin{array}{l}\mathrm{n} / \\
1000\end{array}$ & EMs & $\mathrm{n}$ & $\begin{array}{l}\mathrm{n} / \\
1000\end{array}$ & EMs & $\mathrm{n}$ & $\begin{array}{l}\mathrm{n} / \\
1000\end{array}$ & EMs & $\mathrm{n}$ & $\begin{array}{l}\mathrm{n} / \\
1000\end{array}$ \\
\hline we & 190 & 1.5 & should & 289 & 0.9 & we & 410 & 1.2 & should & 329 & 8 \\
\hline see & 126 & 1.03 & see & 184 & 0.5 & see & 321 & 0.9 & see & 254 & 6 \\
\hline should & 106 & 0.8 & find & 160 & 0.4 & show & 250 & 0.7 & show & 214 & 5 \\
\hline show & 69 & 0.5 & do not & 120 & 0.3 & do not & 218 & 0.6 & we & 162 & 4 \\
\hline do not & 49 & 0.4 & show & 109 & 0.3 & should & 188 & 0.5 & find & 156 & 4 \\
\hline note & 48 & 0.3 & increase & 93 & 0.2 & consider & 115 & 0.3 & do not & 130 & 3 \\
\hline consider & 37 & 0.3 & go & 78 & 0.2 & determine & 82 & 0.2 & us & 96 & 2 \\
\hline determine & 24 & 0.1 & we & 65 & 0.2 & note & 77 & 0.2 & go & 67 & 1 \\
\hline follow & 23 & 0.1 & need to & 63 & 0.1 & find & 71 & 0.2 & consider & 64 & 1 \\
\hline assume & 23 & 0.1 & observe & 42 & 0.1 & recall & 61 & 0.1 & follow & 51 & 1 \\
\hline
\end{tabular}

n: raw frequency of EMs

$\mathrm{n} / 1000$ : frequency of EMs per 1000 words 
Hyland (2002) distinguishes directives as engagement into three categories: textual acts, physical acts, and cognitive acts. The examples below show that the writers guide readers to a particular part of the text ( 1 and 2 as internal reference, and 3 as external reference). Suffice to add that textual acts account for almost half of the directives maintained by the use verb 'see'. In 4, 5, and 6, readers are instructed to specific reasoning (cognitive acts) with the use of 'should', which appeared at high frequencies in the four corpora.

1. (See (4) and (7) for statistics confirming this conjecture) (CMAN, 9).

2. When we looked at the distribution of semantic formulas, it was figured out that the first three semantic formulas preferred by Americans and Turks were different, but this Table did not show the overall distributions (see Appendix 3) (CMAT, 7).

3. (See Cummins, 1981 for further discussion of this concept) (CMAN, 4).

4. These stories should be a reflection of what is occurring in society today (CPhDN, 5).

5. Instead, it should aim to prevent any justification of human species' exploitative activities, and consumption habits (CPhDT, 3).

6. However, when it comes to comparing the isolation that these two characters face throughout the play, it should be noted that Ed is more vulnerable than Sloane. (CMAT, 10).

In 7 and 8, the verb 'see' and the pronoun 'we' (inclusive) construct solidarity by asking readers to identify with particular views and interpretations. The writers probably guide readers to evaluate the interpretations through their lens. As Hyland (2001) states, the use of inclusive we is the most explicit way of bringing readers into the text as discourse participants.

7. We also see a large degree of overlap in the error bars. (CPhDN, 4).

8. Here we see again Ngugi's Marxist personality (CPhDT, 1).

Hyland (2005a) states that 'inclusive we' is the most commonly used engagement device in academic writing, indicating a signal of membership by textually emphasizing similar understanding and goals shared by the writers and the readers. We can see the construction of this solidarity in the examples below. There exists an explicit positioning of readers in the samples. Such a rhetorical strategy has two aims: lessening the risk of readers' objection to the claims and receiving the readers' approval, and getting a place as a member of the discipline. 


\section{F.Yuvayapan-İ.Yakut $\quad$ Engagement Markers in L1 and L2 English...}

9. In Table 5, we see that five factors have high cumulative probability (CPhDN, 2).

10.What we are is the gendered individual constituted according to the rules of difference and deference that makes each meaning, position-dependent on another (CPhDT, 15).

11.This suggests that we are missing something (CMAN, 2).

To conclude, since academic writing is socially constructed, the writers must engage their readers in their texts using different strategies appropriately. Writers bring their readers to the text to reduce the risk of a possible objection to their claims. Their experiences with texts enable them to predict their readers' reactions to the arguments (Hyland, 2005a). Alongside cross-cultural variation between the two groups of academic writers, we found that they follow identical rhetorical strategies in using EMs in their MA and Ph.D. theses, which may explain the influence of several factors.

\section{CONCLUSION}

In four specialized corpora, including MA and Ph.D. theses written by L1 English academic writers and Turkish academic writers of English, we examined the use of engagement devices to figure out persuasive strategies. The comparative corpus-based analysis of EMs shows that both groups of academic writers' in this study attempt to address their readers with similar EMs in both genres, albeit observing cross-cultural variations. EMs guide them to follow their dissertations and focus on critical arguments or claims with the greater use of verbs. The frequent usages of 'inclusive we', 'see' and 'should' reflect their attempts to balance readers' impersonal and personal style of engagement.

Academics must carve a persuasive presentation of their results and interpretations in their academic texts. In this way, they have more chance of becoming a member of their academic discipline. All academic genres exploit cultural and disciplinary variations in the manifestations of academic persuasion. In MA and Ph.D. theses, writers are expected to create writer-reader dialogue and produce structured theses based on linguistic and cultural conventions of the fields, which is the key to constructing themselves as competent academics. In addition, there is increasing pressure on postgraduate students to publish articles in prestigious journals where the medium of communication is in English (Flowerdew, 2016).

Hence, particular attention should be paid to the manifestation of academic persuasion in academic writing courses, which can be achieved by the effective use of EMs regarding cultural and disciplinary conventions. Hyland and Jiang 
(2016) suggest that teachers of English for academic purposes may increase the awareness of critical rhetorical features of academic persuasion. Direct and explicit teaching and learning of EMs may be introduced in these courses. Additionally, a genre-based approach in teaching these devices in academic courses might be beneficial for understanding the conventions and pragmatic functions of EMs. A genre-based approach includes examining and deconstructing the features and main characteristics of genres and creating new texts. Widodo (2006) states that the approach is process-based and rests on the explicit teaching of generic structures. It also encourages the production of texts with a clear purpose, audience, and organization. Derewianka (2003) labels the principles of this approach:

- focus on the text: the construction of meaning throughout the text

- focus on the purpose: meeting culture-specific expectations of the academic community

- focus on meaning and choice: recognizing and making lexical and grammatical choices of the particular genres

- language in context: a language system consisting of culturally constrained choices

- culture and ideology: concerned with specific community and institutions

The present study contributes to our understanding of the employment of engagement markers in two different academic genres and communities. Since the analysis is based on a small corpus, it would not be wise to generalize the results to all post genres and academic writers. A further study could assess the distribution of EMs by following the categorization suggested by Hyland (2005a).

\section{REFERENCES}

Anthony, L. (2019). AntConc (Version 3.5.8) [Computer Software]. Tokyo, Japan: Waseda University. Available from https://www.laurenceanthony.net/software

Baker, P., Hardie, A., \& McEnery, T. (2006). A glossary of corpus linguistics. Edinburgh University Press.

Bastola, M. N. (2020). Engagement and challenges in supervisory feedback: Supervisors' and students' feedback. RELC Journal, 00(0), 1-15. https://doi.org/10.1177/0033688220912547 
Burneikaite, N. (2008). Metadiscourse in linguistics master's theses in English L1 and L2. Kalbotyra, 59, 38-47.

Derewianka, B. (2003). Trends and issues in genre-based approaches. RELC Journal, 34(2), 133-154.

Dontcheva-Navrátilová, O. (2013). Authorial presence in academic discourse: Functions of author-reference pronouns. Linguistica Pragensia, 23(1), 930.

Dontcheva-Navrátilová, O. (2018). Persuasion in academic discourse. In Peclova, J \& Lu, W. (Eds.), Persuasion in Public Discourse: Cognitive and Functional Perspectives, (p. 227- 257). John Benjamin Publishing Company.

Dontcheva-Navratilova, O. (2021). Engaging with the reader in research articles in English: Variation across disciplines and linguacultural backgrounds. English for Specific Purposes, 63, 18-32. https://doi.org/10.1016/j.esp.2021.02.003

Flowerdew, L. (2016). A genre-inspired and lexico-grammatical approach for helping postgraduate students craft research grant proposals. English for Specific Purposes, 42, 1-12. https://doi.org/10.1016/j.esp.2015.10.001

Hyland, K. (2001). Bringing in the reader: Addressee features in academic articles. Written Communication, 18(4), 529-574.

Hyland, K. (2002). Directives: Argument and engagement in academic writing. Applied Linguistics, 23(4), 215-239.

Hyland, K. (2004). Disciplinary interactions: metadiscourse in L2 postgraduate writing. Journal of Second Language Writing, 13, 133-151.

Hyland, K. (2005a). Stance and engagement: A model of interaction in academic discourse. Discourse Studies, 7(2), 173-192.

Hyland, K. (2005b). Metadiscourse: Exploring interaction in writing. Continuum.

Hyland, K., \& Jiang, F. K. (2016). "We must conclude that...”: A diachronic study of academic engagement. Journal of English for Academic Purposes, 24, 29-42. https://doi.org/10.1016/j.jeap.2016.09.003

Irvin, L. L. (2010). What is "academic” writing? Writing spaces: Readings on Writing, Volume $1 . \quad$ Retrieved from 
http://wac.colostate.edu/books/writingspaces1/irvin--what-is-academicwriting.pdf

Koutsantoni, D. (2004). Attitude, certainty and allusions to common knowledge in scientific research articles. Journal of English for Academic Purposes, 3(2), 163-182. https://doi.org/10.1016/j.jeap.2003.08.001

Mameghani, A. A., \& Ebrahimi, S. F. (2017). Realization of attitude and engagement markers in students' presentations. International Journal of Applied Linguistics and English Literature, 6(2), 10.7575/aiac.ijalel.v.6n.2p.73

McGrath, L., \& Kuteeva, M. (2012). Stance and engagement in pure mathematics research articles: Linking discourse features to disciplinary practices. English for Specific Purposes, 31(3), 161-173. https://doi.org/10.1016/ j.esp.2011.11.002

Molino, A. (2010). Personal and impersonal authorial references: A contrastive study of English and Italian Linguistics research articles. Journal of English for academic Purposes, 9(2), 86-101. https://doi.org/10.1016/j.jeap.2010.02. 007

Mur Duenas, P. (2008). Analyzing engagement markers cross-culturally: The case of English and Spanish business management articles. In S. Burgess \& P. Martin-Martin (Eds.), English as an Additional Language in Research Publication and Communication (pp. 197-212). Peter Lang.

Sahragard, R., \& Yazdanpanahi, S. (2017). English engagement markers: A comparison of humanities and science journal articles. Language Art, 2(1), 111-130.10.22046/LA.2017.06

Thompson, G. (2001). Interaction in academic writing: Learning to argue with the reader. Applied linguistics, 22(1), 58-78. https://doi.org/10.1093/ applin/22.1.58

Vázquez Orta, I., \& Giner, D. (2009). Writing with conviction: The use of boosters in modelling persuasion in academic discourses. Revista Alicantina de Estudios Ingleses, 22,219-237.

Widodo, H. (2006). Designing a genre-based lesson plan for an academic writing course. English Teaching, 5(3), 173. 